\title{
Nesne İlişkileri Kapsamında Freudyen Konseptler üzerine bir Literatür Taraması: \\ Oral Saplanımlı bir Histeri Vakası ve Terapi Süreci
}

\author{
Fazilet Canbolat* \\ Orta Doğu Teknik Üniversitesi
}

\begin{abstract}
Özet
Zaman içerisinde histeri tanısı farklı biçimlerde ele alınmıştır. Freud'dan sonraki bazı teorisyenler cinselliği göz ardı edip, histeriyi sınır-durum bozukluğa daha yakın bir perspektifle ele almışlardır. Hastalığın tanımı ve gelişimi farklı biçimlerde yorumlanmış, bu sebeple kavramsal uyuşmazlıklar ortaya çıkmıştır. Ancak, Freud'un teorisi bir bütün olarak değerlendirildiğinde, onun "histeride oral ve ödipal düzeylerde ikili bir saplanma" olabileceğine dair düşüncesi bu uyuşmazlığa bir ç̧̈züm getirebilir. Benzer şekilde, bu makalede hem oral hem de ödipal dönemlerde saplanım yaşamış bir histeri vakası olabileceği düşünülen E. Hanım, Freud'un gelişime dair görüşlerinin bir bütün olarak değerlendirilmesi yoluyla ele alınmış, oral ve ödipal süreçler birlikte analiz edilmiştir. Bu amaçla ilk olarak tanı üzerine tartışılmış, daha sonra Freud'un teorisinin genel özellikleri onun nesne ilişkilerine dair görüşleriyle birlikte aktarılmıştır. Son olarak ise E. Hanım vakası ve terapi süreci Freudyen konseptler ışığında anlaşılmaya çalışılmıştır.
\end{abstract}

Anahtar Kelimeler: Freud, nesne ilişkileri, histeri, sınır-durum bozukluk 


\section{Nesne İlişkileri Kapsamında Freudyen Konseptler üzerine bir Literatür Taraması: Oral Saplanımlı bir Histeri Vakası ve Terapi Süreci}

\section{Tanısal İkilem: Histeri ve Sınır-durum Bozukluk}

Histeri tüm psikanalitik çalışmaların temeli olarak düşünülebilir, zira Freud histerik semptomları olan ünlü Anna O. vakası sayesinde bilinçdışı fantezinin varlığını keşfetmiştir (Fenichel, 1945). Histerinin otantik kavramsallaştırılması konversiyonlar (dönüştürmeler) üzerinedir ve histerinin temel sebebinin yasaklanmış ve dile gelmemiş olan cinsel fantezi olduğu belirtilmiştir (Freud, 1905/1999). Ancak, Millon, Grossman, Millon, Meagher ve Ramnath'ın (2004) bildirdiği gibi klasik psikanaliz kendisini psikoseksüel aşamalardan ve libido'nun belirleyiciliğinden koparıp ego psikolojisine ve nesne ilişkilerine dönüşmüştür. Nesne ilişkileri teorisyenleri ve Freud'u savunan diğer psikanalistler, histeriyi farklı biçimlerde yorumlamış, çoğunluğu cinselliği yok sayıp histeriyi sınır-durum bozukluğa daha yakın bir bakış açısıyla kavramsallaştırmışlardır. Örneğin, Klein (1945) ve Forebrain (1952) histerinin psikoza karşı bir savunma olduğunu, ödipal meselelerden önce ve nesne ilişkileriyle alakalı olarak geliştiğini öne sürmüşlerdir. Diğger yandan, Laphlance (1974) sınır-durum olarak tanımlanabilecek basit bir kişilik yapısı; Kernberg (1984) ödipal dönem öncesinde gelişen bir kişilik yapısı ve sınır-durum patolojilerinden biri; Green (1997) ise sınır-durum kişilik bozukluğunun altında yer alan bir dal olduğunu ifade etmişlerdir (aktaran, Yarom, 2005).

Millon ve diğerleri (2004) psikodinamik yaklaşım içinde sınır-durum patolojiye daha yakın görülen histerik karakterin gelişiminin de tartışmalı olduğunu iddia etmişlerdir. Güncel bilgiler histerik karakterin ödipal ya da oral meselelere bağlı olarak yüksek ya da düşük düzey işlevsellik gösterebileceğini belirtmektedir. Benzer bir biçimde, Kernberg (2004) histerik karakterin daha yüksek düzey fonksiyonellik gösterdiğini; histrionik karakterin ise daha düşük ve çocuksu düzey işlevselliğinin olduğunu ileri sürmüştür. Zetzel (1968), ödipal seviyede saplanmış iyi histeriklerin ve daha ilkel ve oral seviyede saplanmış kötü histeriklerin olduğunu söylemektedir (aktaran, Millon vd., 2004). Ancak farklı teorisyenler aynı kavram için farklı terimler kullanmış, bu yüzden kavramsal uyuşmazlıklar ortaya çıkmıştır. Örneğin, Millon ve diğerlerinin (2004) çocuksu histrionik kişilik alt türü, Kernberg'in (2004) çocuksu kişiliği, Zetzel'in (aktaran, McWilliams, 2011) Zetzel tip 3 ve 4'ü McWilliams (2011) tarafindan kullanılan sınır-durum düzey histrionik kavramı ile ayn kavrama denk gelmektedir.

Psikodinamik Tanı (PDM) (2006) kitabına göre, Mental Bozuklukların Tanısal ve Sayımsal El Kitabı (DSM) histerik tanımını kullanana kadar, psikanalitik uygulamacılar arasında "histerik" nevrotik düzey hastalar için, "histrionik" ya da "histeroid" ise sınır-durum düzey hastalar için kullanılan terimler olmuştur. Millon ve diğerleri (2004) DSM-IV’teki histrionik karakterin oral meselelerle karakterize olan daha ilkel bir form tanımladığını ve histrionik kişiliğe sahip insanların nesne ilişkilerinde ve kişilerarası ilişkilerde daha ciddi sorunlar yaşayabileceğini ileri sürmüşlerdir. Baumbacher ve Amini (1981) ödipal saplanımın histerik karakter ile sonuçlanabileceğini; histerik kişilik bozukluğunun daha erken dönem anne-çocuk ilişkisi ile ilintili olduğunu; histerik özellikler gösteren sınır-durum kişilik organizasyonunun ise direkt olarak oral meselelerle ilgili olduğunu belirtmişlerdir (aktaran, Gabbard, Beck ve Holmes, 2005).

Mullahy'nin (1948) belirttiği üzere, Freud'un teorisini kavramak için, (ödipal karmaşa gibi) tek bir fikrini teorinin geri kalanından ayrı ele almak yerine, ona ait olan her bir düşünce onun insan gelişimine dair diğer düşünceleri kapsamında incelenmelidir. Ayrıca, Marmor (1953) salt histerik kişiliğin olmadığını ve gelişimin önceki basamaklarından kalan tortuların aynı biçimde daha sonraki basamakların özelliklerine serpilmiş biçimde bulunabileceğini ifade etmiştir. Aslında, Freud (1932) histeride oral ve ödipal aşamalarda ikili bir saplanım olabileceğini ileri sürmüştür (aktaran, McWilliams, 2011). Örneğin, histerik semptomları olan Dora'nın oral semptomlar da gösterdiğini fark etmiştir (Marmor, 1953). Benzer biçimde bu makalede, oral düzeyde saplanım yaşayan histerik bir vaka, nesne ilişkileri kapsamında Freudyen kavramlar üzerinden anlaşılmaya çalışılacaktır. 


\section{Freudyen Teoriye İlişkin Genel Kavramlar}

Freudyen teorinin temel özellikleri dürtülerin, içgüdülerin ve insan organizmasının hazzı arzulayan özelliği üzerine kurulu olan yapıların önemini vurgulamasıdır. Freud'un temel kavramlarından biri olan haz ilkesine göre, birey hazzı arzular; acıdan kaçınmak için ise çaba sarf eder (Mullahy, 1948). Freud kişiliği açıklarken genetik ve çevrenin etkisini dengelese de en önemli rolü biyolojik tarafa vermiştir. Onun "dürtü" kavramı kendisini bedensel arzular biçiminde gösteren bilinçdışı ihtiyaç ve istekleri doyurma arzusu olarak tanımlanabilir; ve bir dürtü kendisini bilinç düzeyinde düşünce, duygu veya fantezi olarak gösterebilir (Clair ve Wigren, 2004). Freud'a göre cinsellik ve saldırganlık insan davranışını motive eden en önemli ve temel iki dürtüdür (Kernberg, 1995). Ayrıca, Freud "bir yönde kararlılıkla ilerleyen belirli bir toplamda ya da sayıda enerji” olarak tanımlanan içgüdülere de merkezi bir rol verir (Mullahy, 1948, s.3). Dürtüler bireyin davranışını motive eden devamlı psikolojik yapılardır, içgüdüler ise her ne kadar biyolojik temelli olsalar da çevresel faktörlerden etkilenebilirler; Kernberg'in örneğinde olduğu gibi "Libido bir dürtüdür, açlik ise bir içgüdüdür." (1995, s.17).

Fleming (2004)'in belirttiği üzere, Freud insan zihnini bilinç, bilinç öncesi ve bilinçdış1 olmak üzere üç sistemle kavramsallaştırır. Bir kişinin farkında olduğu duygu ve düşünceleri bilinci oluştururken, bastırılan duygu ve düşünceler bilinçdışının bir temsilidir. Diğer taraftan, bilinç öncesi kişinin belli bir anda bilinçte olmayan duygu ve düşüncelerini bilinç düzeyine getirebildiği bir sistem olarak tanımlanmaktadır (Fleming, 2004). Benzer şekilde, yapısal kişilik modelinde Freud, kişiliğin id, ego ve süperego olmak üzere üç temel yapısı olduğunu söyler. Id, içgüdüsel dürtülerin ihtiyaçlarına ses veren ve haz ilkesine uygun hareket eden, psişik enerjinin kaynağı olan yapı olarak bilinir ve doğuştan itibaren vardır. Gerçeklik ilkesine göre hareket eden ego, id'in dürtülerini kontrol ederek ve dönüştürerek onun ihtiyaçları ve çevresel güçlerin istekleri arasında arabuluculuk yapar. Ego, bebek kendisini dış dünyadan ayırt edip, kendisinin ayrı bir varlık olduğunu fark ettiğinde ortaya çıkar. Ödipal süreçte egonun eylemlerini değerlendirmek üzere ortaya çıkan süperego, ahlak ve toplum kurallarını simgeleyen yapıdır (Clair ve Wigren, 2004). Böylelikle, zihni oluşturan sistemler düşünüldügünde, id tamamen bilinçdışıdır, ego ve süperego ise kısmen bilinç düzeyinde, kısmen bilinçdışıdır (Fleming, 2004).

Ego'nun id ve süperego arasındaki ikilemleri çözme girişimleri olarak tanımlanan savunma mekanizmaları, id ve süperego arasındaki çatışmalar sonucu ortaya çıkan kaygıyla baş edebilmek için de kullanılır (Kahn, 2002). Savunmalar kendini dürtülere ya da duygulanımlara karşı olarak gösterebilir (Freud, 1966). Bastırma, yer değiştirme, yansıtma, gerileme, tersine çevirme, inkâr, somatizasyon, bölme ve eyleme koyma bu savunma mekanizmalarından bazılarıdır. Bastırma mekanizmasını kullanarak ego, id'in dürtülerini kontrol etmeye çalışır ve istenmeyen içgüdüleri bilinçten uzak tutar, bu yolla kişi kaygıyla istila edilmemiş olur (Clair ve Wigren, 2004). Örneğin; çocuk cinselliği teorisine göre, bir birey başından beri cinsel dürtülere sahiptir, ancak cinsel deneyim çocukluk amnezisi dolayısıyla bastırılmıştır (Mullahy, 1948). Yer değiştirme mekanizmasını kullanarak kişi bir duyguyu bir kaynaktan diğerine yönlendirebilir. Yansıtma kişinin kendindeki negatif bir özelliği ya da dürtüyü başka birinin üzerine yüklemesi olarak bilinir. Gerileme gelişimin daha kolay ve zevkli olan daha erken bir aşamasına geri dönme olarak tanımlanır. Bir kişi tersine çevirme mekanizmasını kullanarak gerçek duygularını tersine çevirip buna göre davranabilir. İnkâr tehditi görmezden gelerek, kaygıdan kurtulmanın bir yolu olarak bilinir (Fleming, 2004). Somatizasyon duygusal durumların fiziksel semptomlara dönüştürülmesi olarak kavramsallaştırılır (Stekel, 1924; aktaran, Woolfolk ve Allen, 2007). Freud bölme mekanizmasını farklı şekillerde tanımlar, ancak bu makalede kullanılacağı şekliyle nesnelerin bölünmesi sevginin iyi nesnelerinin ve düşmanlığın kötü nesnelerinin bölünmesi olarak tanımlanabilir. Freud kötü kendilik ve nesnelerin dışsallaştırıldığını, iyi kendilik ve nesnelerin ise içselleştirildiğini öne sürer (Bokanowski ve Lewkowics, 2009). Eyleme koyma hastanın unuttuğu ya da bastırdığı anıları kelimeleri kullanmaktan ziyade davranışlarıyla bilinçdışı bir biçimde ifade etmesi olarak tanımlanabilir; ve Freud'a (1914) göre aktarımdan farklı değerlendirilmemelidir, çünkü ikisi de geçmiş 
bir yaşantıyı tekrarlama durumuyla ilintilidir. Aslında eyleme koyma istenmeyen anıları hatırlamaya karşı kullanılan bir savunmadır (aktaran, Erwin, 2002).

\section{Nesne İlişkileri Kapsamında Freudyen Kavramlar}

Freud'un dürtü/yapı modeli, kişinin dürtülerinin doyurulmasında bir araç olarak tanımlanan nesne kavramına değinerek, nesne ilişskileri teorisine bir giriş yapar (Clair ve Wigren, 2004). Greenberg ve Mitchell (1983) dürtü/yapı modelinde nesnenin tam anlamıyla bir insan olması konusunda teori açısından bir gereklilik olmadığını söylemiştir. Bir dürtünün nesnesi hedef niteliğinde herhangi bir şey de olabilir. Organizmanın hazzı arzulayan itkisi olarak bilinen libidonun cinsellikle eşanlamlı olduğu ifade edilir (Mullahy, 1948), ve libido bir nesneye bağlanma arzusundadır (Burgoyne ve Sullivan, 1999). Freud'un modelinde, nesnenin rolüne kişinin bir dürtüsünü uyandırması ya da doyurması kapsamında ağırlık verilir. Aslında her ne kadar Freud için kişiler arası ilişkiler kayda değer olsa da dürtülerin içgüdüsel çerçevesi onun nesne ilişkileri modelinde odaklanılan nokta olmuştur. Freud'a (1921) göre, bir özne haz veren bir nesneye ulaşmak ve onu kendi egosuna dâhil etmek ister; onu sever. Diğer taraftan acı veren nesneden kaçınır, ondan nefret eder ve onu def etmek ister (aktaran, Clair ve Wigren, 2004).

Freud çocukluk cinselliğini oral, anal, fallik (ödipal), latent ve genital evreler olmak üzere gelişim basamakları şeklinde kategorize eder. Onun gelişim evrelerine dair görüşleri içgüdülerin farklı nesnelere bağlanmasıyla ilgili açıklaması sayesinde anlaşılabilir; zira libidinal enerji farklı evrelerde farklı hedeflere yatırılır (Clair ve Wigren, 2004). Psişik gelişim esnasında cinsel dürtüler libidonun kaynakları olarak bilinen ağız, dudaklar, rektum ya da genitaller gibi farklı erojen bölgelerce harekete geçirilir, bu yüzden Freud'a göre hedefler ve nesneler zaman içinde yer değiştirme yoluyla değişebilir (Kernberg, 1995). Clair ve Wigren (2004) nesne seçimini (kateksi) bir öznenin libidinal ve psişik enerji yatırımı yaptığı nesne olarak; özdeşleşmeyi ise "biri gibi olmak" olarak tanımlamıştır. Onlara göre, özdeşleşme bebeğin bir nesne ile duygusal bağ kurmasının ilkel yoludur. Örneğin, bir bebek annesinin kendi içinde olduğu fantezisine sahiptir. Psişik enerji dışarıdaki gerçek nesne yerine, nesnenin zihindeki temsiline yatırılır ve bu duruma kateksi adı verilir. Freud özdeşleşme ve kateksi arasındaki farkı, özdeşleşmenin nesne kateksisini takip ettiğini ve nesne kateksisini bırakma biçiminin özdeşleşme şeklini belirlediğini söyleyerek anlatır. Oral dönemde özdeşleşme ve kateksinin aynı olduğunu, ödipal süreçte bir farklılaşma yaşandığını söyler. Clair ve Wigren' in (2004) ifade ettiği gibi terk edilen kateksi yetişkin hayatında kalıcı etkilere sahiptir ve terapi esnasında bir noktada aktarım olarak dışa vurulabilir. Bu çerçevede mevcut makalede ele alınacak olan E. Hanım vakasının oral ve ödipal düzeylerde saplanım yaşadığı düşünülmektedir; dolayısıyla özel olarak bu evreler üzerinde durulacak, anal, latent ve genital olmak üzere Freud'un bahsettiği diğer evrelere değinilmeyecektir.

\section{Gelişimin Oral ve Ödipal Dönemleri}

Fleming (2004), Freudyen oral dönemin libido yatırımının ağız çevresinde olduğu zaman dilimi olan doğumla yaşamın ilk iki yılı arasında gerçekleştiğini anlatmıştır. Ayrıca, Mullahy (1948) anne memesinin bebeğin cinsel arzusunun orijinal nesnesi olduğunu, libidinal hazzın emme aktivitesi ile elde edildiğini ifade etmiştir. Gelişimin bu evresinde bebeğin nesne ile olan ilişkisi “oral-yamyamlık" olarak isimlendirilir (Clair ve Wigren, 2004). Diğer taraftan, üç ve altı yaşları arasında gerçekleşen ödipal evrede çocuğun cinselliği falliktir ve genital organlarda toplanmıştır (Fleming, 2004). Bu süreçte, çocuğun libidinal yatırımı ebeveynlerden birinedir; diğer ebeveyn bu yatırımı yasaklayan ve engelleyen bir rakip gibi algılanır ve dolayısıyla çocuğun öldürücü arzularının nesnesi haline gelir. Aynı cinsiyetten ebeveyn ile özdeşleşme ve süperegonun gelişimi, ödipal çatışmanın çözümlenme biçimi olarak düşünülür (Clair ve Wigren, 2004). Bir içgüdü, nesnesine haz ilkesi ile bağlanır, ancak birey bir nesneye saplanım (fiksasyon) geliştirebilir. Saplanım bir içgüdünün nesnesine çok yakın biçimde bağlanması olarak tanımlanır (Mullahy, 1948). 
Freud (1926) bu konuyla ilgili olarak, o dönem tam bir gerekçe sunamasa da, "Bir çocuğun yeni bulduğu haz kaynağını, henüz kaybettiği annesinin meme ucu ile takas şeklinde algılayıp algılamadığını açık bir soru olarak bırakıyorum- daha sonraki fantezilerin işaret ettiği bir olasılık." demiştir (aktaran, Burke, 1998, s. 22). Diğer taraftan, Freud (1933) bir kız çocuğunun ilk sevgi nesnesinin anne olduğunu ancak son nesne seçiminin babaya evrildiğini ileri sürmüştür. Kız çocuğuna dair, "Daha sonra babasıyla ilişkisinde bulduğumuz hemen hemen her şey daha önceki bağlanmasında da vardı ve bilahare babasına transfer edildi." demiştir ve "Ödipal dönem öncesinde anneleriyle olan bağlanmalarını değerlendirmeden kadınları anlayamayız.” diye de eklemiştir (aktaran, Fiorini ve Rose, 2010, s. 15).

\section{Freud'a göre Patoloji ve Psikanaliz}

Freud, patolojinin idin dürtüleri ile ego ve süperego tarafindan desteklenen gerçekliğin dirençli istekleri arasındaki çatışmadan kaynaklı olarak ortaya çıktığını öne sürmüştür. Birinin içgüdüsel dürtüleri kontrol edilemez hale geldiğinde ve savunmalar bu dürtüleri yeteri kadar kapsayamadığında nevrotik çatışma ortaya çıkar ve aslında semptomlar bu çatışmayı dile getirmenin bir yoludur (Clair ve Wigren, 2004). Freud çoklu özdeşimden kaynaklı olarak (hem anne hem babayla özdeşim kurma durumu), histeride çift cinsellikle ilgili bileşenler olabileceğini ileri sürer (Kaplan, 1990). Freud'a göre histeride, kişi kabul edilmeyen ensest arzulara ve ebeveynlerle ters özdeşim kurmaya yani karşı cins ebeveyn ile özdeşim kurmaya karşı bilinçdışı bir savaşım deneyimlediğinde kendi arzularını bastırır (Freud, 1999). Bastırılan materyal, arzunun bir ifade şekli olan vücuttaki fiziksel semptomlar olarak geri döner (Yarom, 2005).

Geleneksel psikanalizde, bilinçdışı işleyiş̧e dikkat etme ve hastanın çağrışımlarına odaklanma önemli temel özelliklerdir. Buna ek olarak psikanaliz, fantezi ve gerçeklikte olanı analiz etme, geçmiş ve şimdi arasındaki ilişkiyi diyalektik bir biçimde anlama, aktarım ve direnmeye karşı dikkatli olma ve vücutla ilgili deneyimleri zihnin durumları açısından açıklamaya çalışma şeklinde bazı temel özellikleri barındırır (Mitchell ve Aron, 1999). Aktarım terapiste karşı olan duyguların bir başkasına yönelik duygularla yer değiştirmesi olarak tanımlanırken, karşı-aktarım terapistin hastaya, yine bilinçdışı yer değiştirme içeren, duygusal cevabı olarak açıklanmıştır (Fleming, 2004). Psikanalizde kullanılan teknikler sembolizm üzerine kuruludur ve rüya analizi, serbest çağrışım gibi teknikler içerir (Fleming, 2004). Verimli bir terapi, bilinçdışı materyali ortaya çıkararak ve hastalara duygularının nasıl savunmalar tarafından örtüldüğünü göstererek; terapistin egonun direnmelerini yakalaması ve üstesinden gelmesi ile gerçekleşir (Mullahy, 1948). Histeriyle ilgili olarak, arzu "konuşma tedavisi”" ile dile döküldüğünde semptomların ortadan kalktığı söylenir (Yarom, 2005).

Mevcut bilgiler göz önüne alındığında, bu makalede E. Hanım vakasının ele alınması uygun görülmüştür; çünkü E. Hanım'ın tanı açısından hem histrionik hem de sınır-durum kişilik örüntülerini düşündüren davranışlar sergilediği gözlemlenmiştir. Dolayısıyla bu vakada oral ve ödipal dönemlerin birlikte değerlendirilmesinin uygun olacağı düşünülmüştür. Bu bağlamda, vaka formülasyonu da bu iki gelişimsel evre üzerinden değerlendirilecek, ardından ise E. Hanım ile terapi sürecine dair bilgi verilecektir.

\section{E. Hanım Vakası}

Yirmi altı yaşında olan E. Hanım, terapiye "kararsızlık, mutsuzluk ve öfke” gibi sebeplerle başvurmuştur. Doktora öğrencisi olduğunu, ancak eğitimine devam etme ya da çalışmaya başlama konusunda kararsızlık yaşadığından dolayı yeterlik seviyesindeyken doktora kaydını dondurduğunu söylemiştir. Mutsuzluğuna dair belirli bir sebebinin olmadığını ifade eden E. Hanım, öfkeli hissetmesinin sebebini eniştesiyle yaşadığı, yazının devamında anlatılacak olan, bir olaya bağlamıştır. İlk seansa ayağı alçı içinde gelen E. Hanım, "Ayağımı kırdım; kendi kendimi düşürdüm.” demiştir; danışanın bu ifadesi kendisine de öfkeli olabileceği yönünde yorumlanmıştır. Başvuru sebeplerine ilişkin tedavi geçmişi olmadığını belirten danışan, şikâyetlerinin geçmişi ile ilgili olarak, altı yaşındayken altını 1slattığını ve annesinin bir psikologla 
görüşme ayarladığını, değerlendirmelere göre de "E.'nin babasına ihtiyacı var.” sonucunun çıktığını söylemiştir. Ayrıca, E. Hanım üniversitenin son sınıfında "mezuniyet, belirsizlik ve gelecek kaygısı" gibi sebeplerle "depresyona" girdiğini, ancak bu durum için herhangi bir tedavi almadığını ifade etmiştir. Hayatının bu dönemini "karanlık dönem" diye adlandırmış, nişanlısının hayatına girmesiyle "aydınlık dönem"e geçtiğini söylemiş̧tir. Terapiden beklentileri sorulduğunda "Dengesiz olmak istemiyorum, nişanlımı üzmek istemiyorum, tırmalamak (tırnaklarla tutunmak) istemiyorum.” demiştir. Bunun anlamı sorulduğunda, E. Hanım “tırmalamak” diye tekrar etmiş, herhangi bir açıklama yapmamıştır.

Ailesiyle ilgili edinilen bilgilere göre, E. Hanım 13 yaşındayken anne ve babası boşanmıştır. Boşanma öncesini hiç hatırlamadığını söyleyen danışan, o döneme dair sadece annesiyle yaşadığı güzel anları hatırladığını belirtmiştir. Boşanma öncesinde annesinin "intihar ediyormuş gibi” yalnızca sigara ve kahve tükettiğini, hiç yemek yemediğini ifade etmiştir. Boşanma sonrası kendisinin ve ablası Deniz'in babasında kaldığını söyleyen danışan bu durumu "Babam boşanmak istemediği için annem bütün haklarından vazgeçmiş." diyerek açıklamıştır. Şu an 33 yaşında olan ablası Deniz'in fiziksel olarak annesine benzerliği dolayısıyla, boşanma sonrası baba ile abla arasında tartışmalar yaşandığını anlatmıştır. Örneğin, bir gün yemek yerlerken babanın ablaya "Bana öyle bakma, annene benziyorsun." demesi ve ablanın babaya bakmaya devam etmesi üzerine tartışma çıktığını anlatmıştır. E. Hanım bu olaylardan bahsederken Deniz'in annesine benzediği kısmı vurgulayıp sesli bir biçimde ağlamıştır. Deniz'in "Ben artık senin annen oldum, burada babamla senin için kaldım." demesine aşırı sinirlendiğini eklemiştir.

Önce babasının, sonra ise annesinin yeniden evlendiğini söyleyen E. Hanım, üvey annesinin kötü niyetli ve kıskanç bir karakter olduğunu dile getirmiştir. Onun iyi bir tarafi olabileceğini oldukça zor kabul etmektedir. Babasının kendilerine sarılmasına engel olduğu için Deniz'le birlikte üvey anneye "Stepzilla" adını taktıklarını söylemiştir. Öz annesiyle olan ilişkilerini anlatırken "süper, güzel, çok iyi” gibi oldukça olumlu atıflarda bulunan danışanın bu atıflara örnek getirmekte zorlandığ 1 gözlemlenmiştir. Babasını genel olarak öfkeli bir kişi olarak tanımlayan E. Hanım, diğer taraftan onu kahraman gibi gördüğünü söyleyip, küçüklüğünde düştüğü ve alnının kanadığı bir anı hatırlamıştır. Babası E'nin yarasını eliyle kapattığı için kanamanın durduğunu söyleyen danışan onun bir kahraman olduğunu eklemiştir. Romantik hayatından bahsederken nişanlısı Haydar'ın “iyi” bir üniversitede yüksek lisans yapan, “önemli” bir kurumda çalışan "muhteşem" bir adam olduğunu söyleyen E. Hanım onun güçlü bir karakter olduğunu ve onu kaybetmekten çok korktuğunu ifade etmiştir. Ablayla şu anki ilişkisindeki gündeminin daha çok rekabet konusu üzerinde olduğu dikkat çekmiştir. Bu konuda örnekler ise genel olarak annenin Ankara'ya geldiğinde kimde kalacağı, babanın onayını kimin alacağı, güzellik ve romantik ilişkilerde kimin daha iyi olduğu şeklindedir.

Eniştesiyle yaşadığı bir olaydan sonra kendisi dâhil herkese karşı çok sinirli olduğunu söyleyen E. Hanım olayı "Bazen ablamlara giderim, içmeli oturmalar yaparız. Ablam yattıktan sonra eniştem Ufuk'la içmeye devam ederiz. Bu gecelerden birinde, Ufuk bana bundan önceki içişimizde çocukken tacize uğradığını söylediğini, benim ona sarıldığımı ve öpüştüğümüzü anlattı. İleri gitmediğimizi, çünkü bakire olduğumu bildiğini söyledi. Ona inanmıyorum. Hatırlamıyorum.” diyerek anlatmıştır. Bu olaydan ve Ufuk'la ilgili diğer anılarından bahsederken danışanın ses tonunun teatral, sı̆̆ abartılı ve dramatize edici olduğu gözlemlenmiştir. Ayrıca, olaya dair hiçbir detay hatırlamadığını söyleyen E. Hanım'ın olayı seanslara gündem olarak getirdiği ancak olay üzerine pek de bir şey söylemediği fark edilmiştir. Diğer taraftan, eniştesinden bahsederken gözlerini devirmesi, “of”laması, konuyu gündeme getirip sonrasında hemen değiştirmek istemesi ve ses tonundaki farklılaşmalar E. Hanım'ın sözel olmayan kanaldan verdiği, bu konuyla ilgili öfkeden ziyade suçluluk hissettiğine dair mesajlar olarak değerlendirilmiştir.

E. Hanım'ın ulaşılabilir bir arkadaşının olmaması ve seanslarda arkadaşlık ilişsilerinden çok fazla bahsetmemesi sosyal ilişkilerinin kısıtlı olabileceğini düşündürmüştür. Seanslar süresince, E. Hanım'ın ilişkilerinde kapalı bir kutuya benzediği, suçlu hissetmekten kaçındığı ve kadınlara karşı yoğun rekabet hisleri içinde, erkekler karşı ise üstü kapalı bir flört durumunda olduğu düşünülmüştür. Bu konu terapi 
süreci başlığı altında daha detaylı irdelenecektir. Diğer insanların kendisiyle ilgili görüşlerini çok fazla önemsediğini söyleyen E. Hanım'ın “El âlem ne der?” sorusunu seanslar süresince de kendisine s1k s1k sorduğu gözlemlenmiştir.

\section{Vaka Formülasyonu}

E. Hanım'ın derinliksiz, teatral ve abartılı duygulanımı, bir sonraki kısımda detaylı olarak değinilecek olan aşırı ilgi ihtiyacı, erkeklere karşı baştan çıkarıcı ya da tahrik edici ve kadınlara karşı rekabetçi tutumu bir arada düşünüldüğünde, danışanın semptomlarının histrionik kişilik örüntüsünü işaret ediyor olabileceği düşünülmüştür. Terapi süreci başlığı altında daha detaylı irdelenecek olan E. Hanım'ın terapi ilişkisindeki sınırları araştıran tavrı ve eyleme koyma mekanizmalarının içeriği düşünüldüğünde, danışanın sınır-durum özelliklere sahip olabileceği de dikkate alınmıştır. Ayrıca danışanın "kendini düşürme, ayağını kırma, cama yumruk atma” gibi kendine zarar verme davranışları; kadınlara karşı rekabet içerikli, erkeklere karşı ise baştan çıkarıcı tutumları dolayısıyla tekrar eden ilişkisel zorlukları; depresyon ve kaygıyla göze çarpan dönemsel yaşantıları, ve ayrışma-bireyselleşme konularında getirdiği gündemler de sınır-durum kişiliği akla getiren özellikler arasındadır.

Ayrışma-bireyselleşme konuları genel olarak danışanın nişanlısı üzerinden gündeme gelmiş, $\mathrm{E}$. Hanım'ın zaman zaman kendi kimliğiyle nişanlısının kimliğini ayırt etmekte zorlandığı ve terk edilmeye dair yoğun kaygılar yaşadığı gözlemlenmiştir. E. Hanım'ın hem histrionik hem de sınır-durum kişilik özellikleri gösteriyor olması sebebiyle, bu vakada oral ve ödipal dönemlerin birlikte değerlendirilmesi gerektiği düşünülmektedir. Daha önce de belirtildiği üzere; ödipal saplanım histerik karakter ile sonuçlanabilir; histerik kişilik bozukluğu daha erken dönem anne-çocuk ilişkisi ile ilintilidir; histerik özellikler gösteren sınır-durum kişilik organizasyonu ise direkt olarak oral meselelerle ilgilidir (Baumbacher ve Amini, 1981; aktaran, Gabbard, Beck ve Holmes, 2005).

Oral ve ödipal dönemlere geçmeden önce danışanın kullandığı savunmaların ele alınmasının da faydalı olacağı düşünülmektedir çünkü E. Hanım'ın somatizasyon, inkâr, bastırma, gerileme ve bölme mekanizmalarını sıkça kullanması, tanı üzerine düşünürken dikkate değer olmuştur. Danışanın çatışmalardan ve hoşuna gitmeyen duygulardan kaçınmak için, kolayca ve hızlıca bir konudan diğerine atladığı gözlemlenmiştir; dolayısıyla id ve süperego arasındaki çatışmalardan kaynaklı olarak ortaya çıkan kaygıyla baş edemediği düşünülen danışanın çözüm olarak savunma mekanizmalarına başvurduğu fark edilmiştir. E. Hanım, "Başıma ağrı girdi.”, "Şuram (göğsünü göstererek) acıyor.” gibi cümlelerle hoşnutsuz olduğu duyguları bedeni üzerinden anlatmaya çalışmaktadır (Somatizasyon). Seanslar süresince "Bilmiyorum.", "Hatırlamıyorum." cümlelerini defalarca kullanmıştır (Bastırma). Ayrıca eniştesiyle ilgili olan yaşantısından bahsederken "Söylersem gerçek olur." diyerek konuyu konuşmaktan kaçınmış, onun kendisine ilaç verip hafızasını silmiş olabileceğini, Türkiye' de bu ilaçtan olmasa da yurtdışındaki dizilerde böyle bir ilaçtan bahsedildiğini söylemiştir. Ek olarak, annesinin boşanma sonrası evden gidişini “Annem bizi değil babamı terk etti." diyerek yorumlayan danışanın acı veren gerçek olaylarla yüzleşmekten kaçındığı düşünülmüştür (İnkar). Bir sonraki bölümde daha detaylı anlatılacağı üzere, zaman zaman E. Hanım'ın davranışlarının tıpkı şımarık ya da küskün bir çocuk gibi olabildiği gözlemlenmiştir (Gerileme). Kendi annesinden bahsederken "Çok iyi bir insandır, fedakârdır. İlişkimiz süper." gibi oldukça olumlu atıflarda bulunan danışan, üvey annesiyle ilgili olaraksa hep negatif anılarından bahsetmiştir. Aynı süreç anneannesi (her şeyiyle iyi) ve babaannesi (her şeyiyle kötü) ile ilgili konuşurken de gözlemlenmiştir. Ayrıca "karanlık dönem" ve "aydınlık dönem” kullanımları olan E. Hanım'ın bölme mekanizmasını da kullanıyor olabileceği düşünülmüştür.

Ödipal dönem göz önünde bulundurulduğunda, E. Hanım'ın id ve süperegosunun (dolayısıyla egosunun da) çarpıştı̆̆ı bir arzu/yasak çatışması içinde olduğu düşünülebilir. Danışanın etik ve estetik değerler açısından diğer insanların kendini değerlendirme biçimini önemsediği açıktır; ancak cinsel yatırımının babasında saplandığı ve bu durumun da toplum tarafından onaylanmadığı düşünüldügünde, bu 
çatışmanın E. Hanım'da kaygıya yol açmış olabileceği düşünülmektedir. Kavramlar üzerinden gidildiğinde, E. Hanım'ın içgüdüsel dürtüleri ona babayı ya da baba gibi olanları elde etmeyi emretmektedir; diğer taraftan ise süperego bu tip ensest içerikli duyguların ahlak tarafından kabul edilmeyeceğini söyleyerek bu duyguları yasaklar. Bu yasak dolayısıyla babaya olan arzu, danışanda kaygı yaratıyor olabilir ve danışan bu kaygıdan korunmak için bastırma, gerileme, inkâr gibi savunma mekanizmalarını kullanıyor olabilir. Bu açıdan bakıldığında, enişte babanın bir ikamesi olarak görülebilir. Baba Ufuk'la yer değiştirmiştir ve E. Hanım Ufuk'a karşı olan cinsel arzusu ve toplumun bu arzuyu yasaklayan duruşu arasındaki çatışmadan dolayı kaygı içerisindedir. Ayrıca, çözümlenememiş ödipal çatışma yüzünden danışan kendisini kadınlarla da bilinçdışı bir rekabet içinde buluyor olabilir. Cinsel arzuları gibi, ablasına, kardeşlerine ve kadın arkadaşlarına karşı hissettiği rekabet de toplum tarafından kabul edilen duygular olmadığı için, E. Hanım'ın bu duyguları da bastırıp mutsuzluk, öfke ve kararsızlık yaşıyor olabileceği düşünülmüştür. Çoğunlukla cinsel hayatıyla ve genel olarak cinsellik konusuyla ilgili konuşmaktan utanıp kaçınsa da, danışanın cinsel fantezisinin aşağılanma ve cinsellik esnasında küfürlü konuşma üzerine olduğu ortaya çıkmıştır. Babasını aşırı sinirli ve sürekli küfreden bir adam olarak tanımlaması, bu fantezinin E. Hanım'ın babasına yönelik libidinal arzusunun bir simgesi olabileceğini düşündürmüştür.

Diğer yandan, vaka daha detaylı incelendiğinde, E. Hanım'ın oral dönemden de çözümlenmemiş meselelerinin olabileceği düşünülmüştür. Terapi ilişkisindeki sinyaller, bu sinyaller terapi kısmında daha detaylı ele alınacaktır, ayrışma-bireyselleşme konusuna dair gelen gündemler ve bölme mekanizmasının aşırı kullanımı oral dönem meselelerini akla getirmiştir. Bu bağlamda, E. Hanım'ın kendi annesine hiç çıkmayan öfkesi ve bu annenin yer değiştirmiş hali olması gereken üvey anne ve kız kardeşe yönelik çıkan düşmanca hisler bir arada değerlendirildiğinde, danışanın kendi annesine karşı bir karşıt tepki oluşturma içerisinde olabileceği düşünülmüştür. Danışanın seansa getirdiği ancak hala çözümlenmemiş konular arasında E. Hanım'ın zeytin görmeye katlanamaması durumu da vardır ve bu konu hala çözümlenmeyi beklemektedir; bu noktada "zeytin" annenin süt kesilmesinden kaynaklı olarak geri çektiği memesinin ucunun bir simgesi olarak düşünülebilir. Oral evredeki çözümlenmemiş nesne kateksisi danışanın özdeşleşmesine ket vurarak ödipal süreçte de saplanım yaşamasına sebep olmuş olabilir. McWilliams'ın da (1994/2013) belirttiği gibi:

Duyarlı ve aç bir küçük kız, bebekliğinde, özellikle, bebeği yanıtlayan anaç bir bakıma ihtiyaç duyar. Bu küçük kız bebeği, kendisini yeterince güvende, doymuş ve değer verilen biri olarak hissettiremeyen annesi hakkında hayal kırıklığı yaşar. Ödipal döneme yaklaşırken, anneyi değersizleştirerek anneden ayrılmayı başarır. Karşılanmamış oral ihtiyaçları ödipal dinamikleri güçlendirecek şekilde daha sonraki genital ilgileriyle birleştiği için özellikle, yoğun sevgi duygusunu, oldukça heyecan verici bir nesne olan babaya yöneltir. Ancak annesiyle hem özdeşleşerek hem de rekabet ederek ödipal çatışmayı normal bir çözüme nasıl kavuşturabilir? Annesine halen ihtiyacı vardır, ama aynı zamanda annesini değersizleştirmişstir de (s. 368).

Benzer bir biçimde, Millon ve diğerleri (2004) psikanalitik perspektife göre, oral saplanımlı histrioniklerin annelerinin genel olarak yetersiz, soğuk ve hissiz olduğunu belirtmiş; bu bakımdan korkmuş, izole olmuş ya da onaylanmamış küçük kız çocuğunun temel bakım verenden öte yeni bir bakım kaynağı bulmayı arzuladığını eklemiştir. Sonuç olarak, anneyi değersizleştirip şiddetle babasına dönen kız çocuğu, normal feminen özdeşleşmeyi de reddetmiş olur. Bu bağlamda, erkekler daha güçlü ve heyecan verici bulunurken, kadınlar zayıf ve muhtaç olarak algılanır, dolayısıyla küçük kız babasına dönüp tüm gücüyle onun dikkatini çekmeye ve onayını almaya çalışır. Danışanın oral dönemine dair net anılar olmasa da, boşanma öncesinde annesinin intihar ediyormuş gibi yalnızca sigara ve kahve tükettiği, hiç yemek yemediği, yani depresif özellikler gösterdiği dönem göz önünde bulundurulduğunda, ailevi problem durumlarında E. Hanım'ın anne bakımı alamadığı yönünde çıkarsama yapılabilir. Ayrıca, üvey kardeşi doğduktan sonra annesinin kendisine "Sizi doya doya sevememiştim." dediğini söyleyen danışanın ilkokul boyunca yatağı 
1slattığına dair bir bilgi de mevcuttur. Bu açıklamaların, E. Hanım'ın kendi annesine karşı kullandığg var sayılan karşıt tepki oluşturma mekanizmasını açıklığa kavuşturabileceği düşünülmektedir. Anne memesine yönelik nesne kateksisini bırakma şekli, E. Hanım'ın ödipal çatışma esnasındaki özdeşleşme sürecinde belirleyici olmuş olabilir. Diğer taraftan, ödipal süreçte özdeşleşme için annesine ihtiyaç duyan E. Hanım, ona karşı olan negatif duygularını bastırıp, yerine karşıt bir tepki olarak yüceltme mekanizmasını getirmiş olabilir. Freudyen teoriye göre, E. Hanım'ın nişanlısı Haydar'ı kaybetmekle ilgili olan korkusu, onun ölmesi ya da onu gerçekten kaybetmeyle ilgili bir arzunun karşıt tepki oluşturma mekanizmasıyla zihinde yeniden yapılandırılmış hali olarak yorumlanabilir. Diğer taraftan bu kaygı danışanın Haydar'la kurduğu özdeşleşme ile ve seanslarda ayrışma-bireyselleşme konusuna dair gündeme gelen (Haydar ile kendi kimliğini ayırt etmekte zorlaması, terk edilmeye dair kaygılar gibi) diğer bilgilerle birlikte de ele alınabilir. Terapi süreci başlığı altında anlatılacağı üzere, E. Hanım'ın nesne olarak anne memesinde yaşadığı düşünülen saplanımın terapötik ilişki içerisinde de zaman zaman kendisini aktarım şeklinde gösterdiği gözlemlenmiştir.

\section{Terapi süreci}

E. Hanım ile olan terapi süreci bir seneyi aşkın süredir devam etmektedir. Bu süreçte terapist, ilişkisel psikanalizden ve şema terapinin yaşantısal tekniklerinden faydalanarak bütünleyici bir yaklaşımla danışanın direncini ve savunma mekanizmalarını ele almaya çalışmıştır. Serbest çağrışım, rüya analizi ve aktarım konuları Freudyen teori kapsamında kullanılan teknikler olmuştur; ancak genel terapi süreci, seans süreleri ve sıklığı ya da divan kullanımı gibi klasik psikanalizin geleneksel yapısını oluşturan öğeleri içermemiştir. Bunun yerine haftada bir, 50 dakika süren yüz yüze görüşmeler gerçekleştirilmiştir. Süreç iki temel adım gibi düşünülecek olursa; terapinin birinci kısmında danışanla güvenilir, sıcak ve sınırları iyi belirlenmiş bir terapi ilişkisi kurmak üzerine yoğunlaşılmıştır; çünkü E. Hanım'ın oral meseleleri (nesne kateksisini bırakma biçimi) terapi ilişkisinde kendisini aktarım biçiminde belli etmiştir. McWilliams (2011) içgörü ve objektiflik üzerinden giden terapinin histrionik hastalar için başlangıçta tehdit teşkil edebileceğini söylemiştir. Bu sebeple ödipal konularla ilgili yüzleştirmeler terapinin ikinci kısmında yapılabilmiştir.

Başlangıç olarak, terapinin odak noktası terapötik ilişki olmuştur, çünkü E. Hanım seanslar içinde eyleme koyma (acting-out) mekanizmasını sıklıkla kullanmış ve psikoterapinin sınırlarını araştırmaya çalışmıştır. Eyleme koyma mekanizmasına bir örnek olarak, seanslardan birinde babasının kendisini terapiye gelirken gördüğünü anlatan E. Hanım'ın içe çekildiği gözlemlenmiştir. Terapistle göz kontağını kesen ve terapistin sorduğu sorulara hiçbir yanıt vermeyen danışan kapalı bir kutu gibi olmuştur. Terapist karş1-aktarım üzerinden giderek, kendindeki dışarıda bırakılmışlık hissine benzer bir duyguyu danışanın daha önce hiç yaşayıp yaşamadığını sormuştur. Bu yolla, E. Hanım çocukluğunda arkadaşları tarafından dışlandığını anlatmaya başlamıştır. Bu dışarıda bırakılmışlık hissinin, danışanın fallik süreçte yaşadığ 1 var sayılan "ödipal üçgende dişarıda kalma" durumuyla ilgili olabileceği de düşünülmüştür, ancak terapinin bu aşamasında erken bir yorum olabileceği için bu yorum danışanla paylaşılmamıştır. Danışanın kendinde var olmasını istemediği izolasyonla ilgili duyguları terapiste davranışlarıyla yansıtarak baş edip, bu şekilde anlaşılmaya çalışıyor olabileceği düşünülmüş̧ür (Eyleme koyma).

Bir sonraki seansa geldiğinde E. Hanım çoğu zaman kapalı kutu gibi davrandığını, bunu ilgi çekmek ve sevildiği konusunda kendisini ikna etmek için yaptığını söylemiştir, dolayısıyla kapalı kutunun açılmaya başladığı düşünülmüştür. Başka bir seansa ağzında sakızla gelen E. Hanım, görüşme esnasında masanın üzerine yatarak, kalem çevirerek, kalemin kapağını takıp çıkararak konuşmuş ve unuttuğu anıları hatırlamasına yardımcı olabilecek bir araç olarak düşünülen çocukluk fotoğraflarını masanın üzerine, terapistin önüne firlatmıştır. "Şu an burada, bizim aramızda ne oluyor?" sorusu üzerine E. Hanım kendisini 11 yaşında şımarık bir çocuk gibi hissettiğini söylemiştir. Eyleme koyma ele alındığında danışanın 11 yaşında sahip olduğu sabit aile şartlarına geri dönme arzusu ( gerileme) ortaya çıkmıştır ve ardından terapide sınırlar üzerine konuşularak seansa devam edilmiştir. Daha sonra, E. Hanım seans bittiğinde terapistin arabasıyla 
bir yere kadar bırakılmayı rica etmek, seans öncesi terapistle havadan sudan konuşmaya çalışmak, seans içinde hep kendi hakkında konuşulduğunu belirterek terapist hakkında da konuşmak istediğini söylemek gibi örneklerle açıklanabilecek biçimde terapinin sınırlarını araştırmaya başlamıştır. Bu aşamada psikoterapinin kuralları danışana hatırlatılmış, bu davranışlar danışanın yakınlık ihtiyacı üzerinden ele alınmıştır. Başka bir seansta, terapiyi "köşe kapmaca" oyununa benzettiğini söyleyen danışan kendisinin kaçtığ peşinden kovalayan taraf olduğu izlenimini yaratmıştır. Bunun anlamı araştırıldığında E. Hanım'ın bilinçdışı davranışlarla terapisti kızdırmaya çabaladığı ve aile üyeleri tarafından maruz kaldığı öfkeyi terapistte tekrar oluşturmaya çalıştı̆̆ı sonucuna varılmıştır (Eyleme koyma). Babasının, ablasının, üvey ve öz annesinin kendisine öfkeli olduğunu söyleyen danışan "Hasta olunca, düşünce, böcekten korkunca babam kızardı." diye duruma örnek getirmiştir. Başka bir örnekte, 15 yaşındayken okul servisini kaçırdığı için babasının kendisini okula bıraktığını söyleyen danışan, onun kendisine yol boyunca bağırıp küfrettiğini ağlayarak anlatmıştır. Annesininse mastürbasyon yaptığı zamanlarda kendisine kızdığını ve vurduğunu söyleyen E. Hanım, ablasının ve üvey annesinin de öfkeli tipler olduğunu belirtmiştir. Bu içgörünün danışanda oldukça etkili olduğu gözlemlenmiş, daha sonraki seanslarda terapötik ilişki daha optimal bir seviyeden devam etmiştir. Örneklerden de görülebileceği üzere, terapist terapinin ilk safhasında seanslarda oluşan durumları yorumlarken daha ilişkisel bir yöntem benimsemiştir ve sağlıklı terapi sınırlarını korumaya çalışmıştır.

Ayrıca, bazı yorumlayıcı müdahalelerle E. Hanım'ın dikkatini bastırılan duyguları hatırlama üzerine çekmeye çalışmıştır. Terapinin bu aşaması, danışanın bebekliğinde annesinin memesiyle olan ilişkisinin bir yansıması olarak düşünülebilir. Süt kesilmesinden dolayı bebekliğinin erken bir döneminde annenin memesi geri çekildiği için, E. Hanım tıpkı sütü içinde tutan bir meme gibi, başlarda bilgiyi kendisine saklamış olabilir. Bu bağlamdaki eyleme koyma E. Hanım'ın gelişiminin oral döneminde yaşadığı nesne kateksisinin bir tekrarı biçiminde yorumlanabilir. Ayrıca, danışanın oral engellenmesi terapide kendisini gerileme biçiminde ve kızılıp cezalandırılma korkusu biçiminde göstermiş olabilir. Başlangıçta E. Hanım terapisti bir hasım ya da ona kızıp cezalandırabilecek biri olarak algılasa da, ilişki ele alındıkça terapötik ilişkinin gelişmeye başladığı gözlemlenmiştir. Süreç içerisinde, E. Hanım'ın eyleme koyma mekanizmasını seans içinde kullanımı gözle görülür biçimde azalmış, danışanın duygularını davranışlarıyla değil, sözel olarak dile getirebildiği görülmüştür.

Güvenilir, sıcak ve sınırları iyi belirlenmiş bir terapi ilişkisi kurulduktan sonra, terapinin ikinci aşamasında danışanın süreçlerinde ödipal saplanım ile ilgili olabileceği düşünülen noktalar ele alınmaya başlanmıştır. Yapılan imgelem çalışmalarından birinde E. Hanım güvenli alanı "Sabahçıyken erken kalkınca çok üşürdüm. Annem kahvaltı hazırlıyorken babamın yanında yatardım, sıcacıktı." diyerek anlatıp ağlamaya başlamıştır. Bu güvenli alanın, E. Hanım'da var olduğu düşünülen ödipal süreçlerle uyumlu olduğu düşünülmüştür.

Terapi süreci devam ederken danışan nişanlısıyla evlenmiştir. E. Hanım, kadın arkadaşlarından birinin kendisini üzecek ve kıracak biçimde davrandığını seansa gündem olarak getirdiğinde, konunun içeriğine dair bilgi alınmış ve Haydar'la balayından iki hafta sonra danışanın kendi bölüm arkadaşlarıyla İzmir'e tatile gittiği, Haydar'ın kendisiyle birlikte bu tatile gelmediği, ancak kadın arkadaşlarının partnerleriyle geldikleri öğrenilmiştir. Terapist, tatilde yaşananları danışanın daha detaylı anlatmasını istemiştir. Bu noktada, danışanın getirdiği detaylara yönelik sorular sorup bekleyen terapist özellikle danışanın ve tatil arkadaşlarının hissetmiş olabilecekleri üzerinde durmuştur. Terapistin sorularıyla, E. Hanım'ın kendisine kötü davranan kadın arkadaşının kocasına karşı bilinçdışı bir biçimde baştan çıkarıcı ve flörtöz bir tutum içinde olduğu ve arkadaşının bu yüzden kendisine kızıp kötü davrandığı temaları ortaya çıkmıştır. Bu içgörünün danışanın olaya bakış açısını değiştirdiği ve E. Hanım'ın arkadaşlarına yönelik tutumlarının farklılaştığı (örneğin; kadın arkadaşıyla yeniden ve daha samimi bir biçimde iletişim kurmaya çalıştı̆̆ı) gözlemlenmiştir, ancak danışanın abla ve enişte hususunda ödipal saplanmadan kaynaklı rekabet dinamiklerine dair iç görü edinmekten kaçındığı da dikkat çekmiştir. Diğer taraftan ilerleyen seanslarda, 
eniştesiyle yaşanan olayda kendisine de sinirlendiğini ifade eden danışan "Başkasının gözünden hata yapan birine, kendime bakıyor gibiyim. Ablamın gözünden..." diye eklemiştir. "Romanlarda olur ya: Yaptığımın yanlış olduğunu biliyordum ama çok mutluydum. Öyle bir şey yok.” diyen E. Hanım'ın eniştesine karşı arzusunu suçluluk duygusu dolayısıyla inkâr ediyor olabileceği düşünülmüştür.

Terapist de kadın olduğu için, E. Hanım'ın rekabetçi tutumunun seanslar içinde de zaman zaman kendini göstermeye devam ettiği gözlemlenmiştir. Örneğin, 31. seans "kaçmak" ve "terapiste yakalanmak" temaları ele alınırken E. Hanım yetersizlik duygularından bahsetmiştir. Başka bir seans terapiste "Papucumun Ajanı" adında bir kitap öneren danışan, biyolojiyle ilgili bir konudan bahsederken "Kendimi öğretmen gibi hissettim." demiştir. Bu bağlamda, danışanın pozisyon açısından terapistle rekabete girmiş olabileceği düşünülmüştür. Ayrıca, E. Hanım'ın her seansın ilk 10 dakikası evlilikten bahsettiği fark edilmiş ve bunun sebebi soruduğunda danışan ablasına da sık sık evlilik hazırlıklarından bahsettiğini, onunsa sıkıldığını ifade etmiştir. "Ablam nişanlıyken gezememiş. Onun bu süreci benim kadar yaşayabildiğini pek sanmıyorum.” deyip şartlarının ablasına göre daha iyi olmasının kendisini sevindirdiğini, ablasını ise kıskandırdığını dile getirmiştir. Terapist kendisinin de yüzüğü olmadığını söyleyince, E. Hanım “Ay çok utandım, hiç farkında değilim.” demiştir.

E. Hanım, belli bir süre boyunca, Haydar ile olan evliliklerinin sürekli olarak ve sadece iyi yanlarından bahsetmiştir, nitekim evliliğe ya da ilişkiye dair hiç negatif gündem getirmemiştir. Ancak, seanslardan birinde çok korkunç bir kâbus gördüğünü söyleyen E. Hanım, "Her yerde patlamalar vardı, toprak duvarlara çarpıyordu. Ben, Haydar ve Haydar'ın kardeşi patlamaları kaynanamın evinden izledik." diyerek anlatmıştır. E. Hanım'ın rüyaya dair duygularıyla ve kâbusu anlatırken kullanmayı seçtiği sözcüklerle ilgili sorular sorulduğunda, danışanın ilk cinsel birleşme esnasında oldukça kaygılı olduğu açığa çıkmıştır (duvara çarpma), ve Haydar'ın kendisine göre erken boşaldığı bilgisi edinilmiştir (patlama). Eşinin kendisine göre erken boşalma durumunu “O, çoğu zaman benden önce orgazm oluyor.” diyerek anlatan danışan hiç vajinal orgazm yaşamadığını da zorlanarak söylemiştir. Bu açıdan, terapötik ilişkinin başlangıca kıyasla daha iyi bir durumda olduğu düşünülse de danışanın ödipal meselelerinin ve terapist dahil kadınlara yönelik rekabetçi tutumunun devam ettiği düşünülmüştür. Bu durum danışanın cinsel problemler, evlilikle ilgili sorunlar gibi bazı gündemleri seansa getirmesine ket vurmuş olabileceği düşünülmüştür. Diğer taraftan, başlarda rekabetle ilgili olarak “Orada bir şey var ve dokunamıyormuşum gibi.” diyen E. Hanım'ın son seanslara doğru rekabetle ilgili gündemleri (örneğin arkadaşları, ablası ve kardeşleri üzerinden) daha rahat seansa getirdiği gözlemlenmiştir. Bu sebeple, ödipal meseleleri ve rekabeti ele almaya devam etmek, terapinin devam eden amaçları arasında yer almaktadır.

\section{Sonuç}

Bu makalede, hem oral hem de ödipal dönemlerde saplanım yaşamış bir histeri vakası olabileceği düşünülen E. Hanım, Freud'un gelişime dair görüşlerinin bir bütün olarak değerlendirilmesi ve devam eden nesne kateksisinin anlaşılması yoluyla ele alınmıştır. Başka bir deyişle, bir histeri vakasında oral ve ödipal süreçler birlikte analiz edilmiştir. Bu amaçla ilk olarak tanı üzerine tartışılmış, daha sonra Freud'un teorisinin genel özellikleri onun nesne ilişkilerine dair görüşleriyle birlikte aktarılmış ve son olarak ise E. Hanım vakası ve terapi süreci Freudyen konseptler 1şığında anlaşılmaya çalışılmıştır. Sonuç olarak, bu vaka analizi oral saplanımlı bir histeri vakasının tedavi sürecine örnek teşkil etmektedir. Sınır-durum kişilik ve histerinin literatürde de kıyaslanan ve benzerlikleri üzerinde durulan iki patoloji olduğu düşünülürse, mevcut çalışmanın bu iki patolojinin kesişim noktası olabileceği varsayılan oral saplanımlı histeri vakaları için klinik veri sağlayabileceği düşünülmektedir. 


\section{Kaynaklar}

Bokanowski, T. ve Lewkowics, S. (2009). On Freud's "Splitting of the ego in the process of defence". London: Karnac Books.

Burgoyne, B. ve Sullivan, M. (1999). The Klein-Lacan dialogues. New York, NY: Other Press.

Burke, N. (1998). Gender and envy. New York, NY: Routledge.

Clair, St. M. ve Wigren, J. (2004). Object relations and self psychology: An introduction. Canada, Thomson Learning Inc.

Erwin, E. (2002). The Freud encyclopedia: Theory, therapy and culture. New York, NY: Taylor \& Francis. Fenichel, O. (1945). The psychoanalytic theory of neurosis. New York: Norton.

Fiorini, L. G. ve Rose, G. A. (2010). On Freud's femininity. London: Karnac Books.

Fleming, J. S. (2004). Freud and the psychodynamic approach to development (Chap. 8). http://swppr.org/Textbook/Ch\%208\%20Freud.pdf . Erişim tarihi: 20.08.2016

Freud, S. (1999). Psikopatoloji üzerine (S. Budak, Çev.). Ankara: Öteki Yayınevi. (1905).

Gabbard, G. O., Beck, J. S. ve Holmes, J. (2005). Oxford textbook of psychotherapy. New York: Oxford.

Greenberg, J. R. ve Mitchell, S. A. (1983). Object relations in psychoanalytic theory. USA, Harward University Press.

Kaplan, E. A. (1990). Psychoanalysis \& Cinema. London, Routledge.

Marmor, J. (1953). Orality in the hysterical personality. Journal of American Psychoanalytic Association. 1(4). 656-671.

McWilliams, N. (2013). Psikanalitik Tanı: Klinik süreç içinde kişilik yapısını anlamak (E. Kalem, Çev.). İstanbul: İstanbul Bilgi Üniversitesi Yayınları. (Orijinal çalışma 1994 yılında yayımlanmıştır).

McWilliams, N. (2011). Psychoanalytic diagnosis: Understanding personality structure in the clinical process. New York, NY: Guilford Press.

Millon, T., Grossman, S., Millon, C., Meagher, S. ve Ramnath, H. (2004). Personality disorders in modern life (2nd ed.). Canada, New Jersey: John Willey.

Mitchel, S. A. ve Aron, L. (1999). Relational psychoanalysis: The emergence of a tradition. USA, The Analytic Press.

Mullahy, P. (1948). Oedipus myth and complex: A Review of Psychoanalytic Theory. New York, NY: Evergreen Edition.

Kahn, M. (2002). Psychoanalytic thought for the twenty first century. New York, NY: Basic Books.

Kernberg, O. F. (1995). Love relations: Normality and pathology. USA, Yale University Press.

Kernberg, O. F. (2004). Borderline conditions and pathological narcissism. USA: Rowman \& Littlefield

Publishers, Inc.

Psychodynamic Diagnostic Manual Task Force. (2006). Psychodynamic diagnostic manual. Silver Spring, MD: Alliance of Psychoanalytic Organizations.

Woolfolk, R. L. ve Allen, L. A. (2007). Treating somatization: A cognitive-behavioral approach. New York, NY: The Guilford Press.

Yarom, N. (2005). Matrix of hysteria: Psychoanalysis of the struggle between the sexes as enacted in the body. New York, NY: Routledge. 


\section{Summary \\ A Review of Literature on Freudian Concepts within the Scope of Object Relations: A Case of Orally Fixated Hysteria and the Therapy Process}

Hysteria can be counted as the basement of all classical psychoanalytic work, considering that Freud discovered the presence of "unconscious phantasy" through studying on his famous case of Anna O. who had hysterical symptoms (Fenichel, 1945). The authentic conception of hysteria was on conversions, and it indicated that unexpressed and forbidden sexual phantasy is the main cause of hysteria (Freud, 1905/1999). Throughout the time, the diagnosis of hysteria has been handled in different styles; the theoreticians, after Freud, avoided sexuality and conceptualized hysteria from a perspective closer to borderline. Indeed, recently according to psychodynamic theoreticians, oedipal fixation results in hysterical character; hysterical personality disorder is more related to dyadic mother-child relationship; and borderline personality organization with hysterical features is directly related to oral issues (Baumbacher \& Amini, 1981, as cited in Gabbard, Beck \& Holmes, 2005). The definition and the generation of the disease are interpreted differently; therefore, a conceptual controversy is emanated. However, when Freud's theory is evaluated as a whole, his idea of "a binary fixation in hysteria both at oral and oedipal levels" may be a solution for this controversy.

In 1933, Freud declared that the first love object of a girl is the mother but then her final object choice becomes the father. Regarding a girl, he stated that "almost everything that we find later in her relation to her father was already present in their earlier attachment and has been transferred subsequently onto her father"; and he added that "we cannot understand women unless we appreciate this phase of their pre-Oedipus attachment to their mother." (as cited in Fiorini \& Rose, 2010, p. 15).

Congruently, an orally fixated hysteric case, the case of Mrs. E., was analyzed in the current paper by trying to understand Freud's notions of development; oedipal stage in conjunction with the oral stage. With this subject in mind, first of all the diagnosis was debated; secondly the general characteristics of Freud's theory were given with the accompany of his ideas related to object relations, pathology and psychotherapy; and lastly the case of Mrs. E. and the therapy process with her were described in the light of Freudian concepts.

Keywords: Freud, psychoanalysis, object relations, histrionic personality, hysteria, borderline 